\title{
Androgen secretion and characteristics of testicular hCG binding in cryptorchid rats
}

\author{
B. D. Schanbacher
}

Roman L. Hruska U.S. Meat Animal Research Center, Science and Education AdministrationAgricultural Research, U.S. Department of Agriculture, Clay Center, Nebraska 68933, U.S.A.

\begin{abstract}
Summary. Response of the cryptorchid testis to gonadotrophic stimulation was assessed by comparison of the androgen production capability in vivo and in vitro with that of the normal scrotal testis. Serum androgen concentrations in cryptorchid rats were similar to those in normal rats, and the incremental increase 60 min after 50 i.u. hCG (i.v.) was about 7 -fold for both groups. Basal and hCG-stimulated androgen production in vitro was higher for abdominal testes (557 and 3286 $\mathrm{ng} /$ pair) than for scrotal tests (157 and $504 \mathrm{ng} / \mathrm{pair}$ ). Specific binding of hCG by testicular homogenates was slightly higher $(P<0.05)$ for cryptorchid testes when expressed per unit weight, but Scatchard analysis indicated that although hCG binding affinities did not differ $\left(K_{\mathrm{a}}=2 \times 10^{10} \mathrm{M}^{-1}\right)$, hCG binding capacity of cryptorchid testes was only $75 \mathrm{ng}$, compared to $219 \mathrm{ng}$ for scrotal testes. These data indicate that a discrepancy exists between androgen production in vivo and in vitro by cryptorchid testes and that normal serum androgen concentrations are maintained in the presence of decreased numbers of testicular LH/hCG receptors.
\end{abstract}

\section{Introduction}

Induced cryptorchidism in rats results in testicular damage which is accompanied by increased circulating levels of LH and FSH (Swerdloff, Walsh, Jacobs \& Odell, 1971; Rager, Zarzychi, Eichner \& Gupta, 1975; Gomes \& Jain, 1976; de Kretser, Sharpe \& Swanston, 1979; Kerr, Rich \& de Kretser, 1979). Similar responses are obtained after heat treatment of the testes (Aaf jes, Vreeburg \& Schenck, 1978). Although testosterone can suppress these elevated levels of gonadotrophins (Aafjes et al., 1978), increases and decreases in circulating concentrations of testosterone after bilateral cryptorchidism have been reported (Amatayakul, Ryan, Uozumi \& Albert, 1971; Lloyd, 1972). Clegg (1961) reported that artificial cryptorchidism was followed by a transient increase in the numbers of interstitial and Leydig cells of the rat testis, and the binding capacity for hCG by cryptorchid testes is enhanced on a per unit weight basis (Frowein \& Engel, 1975; de Kretser et al., 1979). The objective of the present study, therefore, was to determine the androgen secretory response of cryptorchid rat testes in vivo and in vitro and relate these findings to testicular hCG binding characteristics.

\section{Materials and Methods}

Animals. Mature male rats weighing approximately $300 \mathrm{~g}$ each were used. The 24 rats in Group 1 were sham operated (controls) and the 24 in Group 2 were made bilaterally cryptorchid as described previously (Schanbacher, Gomes \& VanDemark, 1974). The consequences of induced cryptorchidism were assessed 30 days later in 3 ways. 
Androgen secretion in vivo. Serum androgen concentrations were measured in 10 control and 10 cryptorchid rats immediately before and $60 \mathrm{~min}$ after an intravenous injection of 50 i.u. hCG. Blood was collected and the hormone injected by cardiac puncture under light ether anaesthesia. The animals were subsequently killed to check the position of the testes and whether any adhesions or abnormalities had resulted. Weights of the testes and seminal vesicles were recorded.

Androgen production in vitro. The incubation system described by Dufau, Catt \& Tsuruhara (1971) and modified by Bartke, Williams \& Dalterio (1977) was used to determine testosterone production in vitro of testicular tissue from 10 control and 10 cryptorchid rats. After death by cervical dislocation, the testes were immediately removed, decapsulated and incubated individually in $5 \mathrm{ml} \mathrm{Krebs-Ringer} \mathrm{bicarbonate} \mathrm{buffer} \mathrm{containing} 1 \mathrm{mg}$ glucose $/ \mathrm{ml}$. One testis from each animal was incubated in the absence of gonadotrophin to estimate basal testosterone production; the other testis was incubated in the presence of $50 \mathrm{mi.u}$. hCG/ml to estimate stimulated testosterone production. Testes were incubated at $37^{\circ} \mathrm{C}$ for $4 \mathrm{~h}$ and the media were then collected after centrifugation at $1500 \mathrm{~g}$ for $5 \mathrm{~min}$.

$h C G$ binding. A procedure similar to that described by Bex \& Bartke (1977) for the hamster testis was used to determine gonadotrophin binding to crude homogenates of testes from 4 control and 4 cryptorchid rats. After death by cervical dislocation, testes were excised, decapsulated, weighed to the nearest $\mathrm{mg}$ and then homogenized in a ground-glass tissue homogenizer together with $5 \mathrm{ml}$ ice-cold $10 \mathrm{~mm}$-phosphate buffer (PBS) containing $1 \mathrm{~mm}$-EDTA, $140 \mathrm{mM}$ $\mathrm{NaCl}$ and $15.4 \mathrm{~mm}^{-\mathrm{NaN}_{3}}(\mathrm{pH} \mathrm{7.5)}$. The homogenate was centrifuged at $1500 \mathrm{~g}$, and the resultant tissue pellet was resuspended in PBS at a concentration of $1 \mathrm{~g} / 5 \mathrm{ml}$. This preparation was used immediately or frozen at $-70^{\circ} \mathrm{C}$ until assayed for hCG binding.

Radiolabelled hCG was prepared by iodination of purified hCG (CR 119: $11600 \mathrm{i} . \mathrm{u} . / \mathrm{mg}$ ) with $0.5 \mathrm{mCi}{ }^{125} \mathrm{I}$ (New England Nuclear, buffered preparation). Chloramine $\mathrm{T}(5 \mu \mathrm{g})$ was used to iodinate $2.5 \mu \mathrm{g} \mathrm{hCG}$ in a reaction vessel for $30 \mathrm{sec}$. The radiolabelled hCG was separated from free iodide on a $1 \times 22 \mathrm{~cm}$ Bio-Gel P-100 column eluted with PBS. Specific activity of ${ }^{125}$ Ilabelled, hCG determined by self-displacement in the rat testis receptor assay, was estimated at $47 \mu \mathrm{Ci} / \mu \mathrm{g} \mathrm{hCG}$ (CR 119). Sensitivity of the binding-inhibition curve was $<0.5 \mathrm{ng}$ hCG.

The binding of hCG was determined for $100 \mu$ aliquots $(20 \mathrm{mg})$ of testicular homogenate. Each tube received 55000 c.p.m. (528 pg) of ${ }^{125}$ I-labelled hCG and either 0 or 100 i.u. hCG in a total of $0.5 \mathrm{ml}$ PBS. All samples were run in duplicate at $20^{\circ} \mathrm{C}$. Following a $20 \mathrm{~h}$ incubation $2 \mathrm{ml}$ ice-cold PBS were added, and the samples were centrifuged at $1500 \mathrm{~g}$ for $15 \mathrm{~min}$. The supernatants were removed and the sediments counted in a spectrometer (No. 5385, Packard). Specific binding of ${ }^{125} \mathrm{I}$-labelled hCG was calculated as total binding (c.p.m.) minus non-specific binding (c.p.m.). Self displacement curves for a representative normal and cryptorchid rat were used to generate the Scatchard plots (Scatchard, 1949) and calculate the binding affinity and number of binding sites for each preparation.

Concentrations of androgen (testosterone $+5 \alpha$-dihydrotestosterone) in serum and incubation media were determined by radioimmunoassay (Schanbacher, 1976). The sensitivity was $0.2 \mathrm{ng} / \mathrm{ml}$ and the intra-assay coefficient of variation was $<12 \%$ for each duplicate.

Differences between means were tested statistically by Student's $t$ test.

\section{Results}

Testicular weight was reduced markedly after 30 days of induced cryptorchidism (Table 1), but seminal vesicle weight was maintained and serum androgen concentration was not significantly different from that in controls. The ability of the cryptorchid testis to secrete testosterone in response to hCG appeared normal because serum androgen increased similarly. 
Table 1. Effect of surgically induced, bilateral cryptorchidism on weights of the testes and seminal vesicles and serum androgen response to hCG by rats in vivo

\begin{tabular}{|c|c|c|c|c|}
\hline \multirow[b]{2}{*}{ Rat } & \multirow{2}{*}{$\begin{array}{c}\text { Wt of } \\
\text { paired testes } \\
\text { (g) }\end{array}$} & \multirow{2}{*}{$\begin{array}{c}\text { Wt of } \\
\text { seminal vesicles } \\
\text { (g) }\end{array}$} & \multicolumn{2}{|c|}{ Serum androgen $(\mathrm{ng} / \mathrm{ml})$} \\
\hline & & & Before hCG & After hCG* \\
\hline $\begin{array}{l}\text { Sham-operated } \\
\text { Cryptorchid }\end{array}$ & $\begin{array}{l}3.81 \pm 0.06 \\
1.25 \pm 0.08 \dagger\end{array}$ & $\begin{array}{l}1.16 \pm 0.10 \\
0.93 \pm 0.07\end{array}$ & $\begin{array}{l}6.8 \pm 0.7 \\
6.0 \pm 0.6\end{array}$ & $\begin{array}{l}42.0 \pm 4.4 \\
40.1 \pm 4.7\end{array}$ \\
\hline
\end{tabular}

Values represent mean \pm s.e.m. for 10 normal and 10 cryptorchid rats.

* At 60 min after 50 i.u. hCG given i.v.

$\dagger$ Significantly different from corresponding value for control rats: $P<0.01$.

As shown in Table 2, basal androgen production in vitro was considerably higher for abdominal testes than for scrotal testes. Stimulation by hCG enhanced androgen production for both groups, but the response by cryptorchid testes was significantly greater.

Table 2. Effect of surgically induced, bilateral cryptorchidism on basal and hCG-stimulated $(50 \mathrm{mi} . \mathrm{u} . / \mathrm{ml})$ androgen production by the rat testis in vitro over $4 \mathrm{~h}$

\begin{tabular}{|c|c|c|c|c|}
\hline \multirow[b]{2}{*}{ Testes } & \multicolumn{2}{|c|}{ Basal testosterone production } & \multicolumn{2}{|c|}{ Stimulated testosterone production } \\
\hline & $\begin{array}{c}\text { Per } \mathbf{g} \text { testis } \\
\text { (ng) }\end{array}$ & $\begin{array}{l}\text { Per paired } \\
\text { testes (ng) }\end{array}$ & $\begin{array}{c}\text { Per g testis } \\
\text { (ng) }\end{array}$ & $\begin{array}{l}\text { Per paired } \\
\text { testes (ng) }\end{array}$ \\
\hline $\begin{array}{l}\text { Scrotal } \\
\text { Abdominal }\end{array}$ & $\begin{array}{c}49 \pm 12 \\
732 \pm 70^{* *}\end{array}$ & $\begin{array}{l}157 \pm 39 \\
557 \pm 186^{*}\end{array}$ & $\begin{array}{c}155 \pm 20 \\
4226 \pm 697^{* *}\end{array}$ & $\begin{array}{c}504 \pm 69 \\
3286 \pm 608^{* *}\end{array}$ \\
\hline
\end{tabular}

Values represent mean \pm s.e.m. for 10 scrotal and 10 abdominal testes, each from individual rats.

Significantly different from corresponding value for scrotal testes: ${ }^{*} P<0.05$; $* P<0.01$.

Specific binding of hCG by testicular homogenates of cryptorchid rat testes $(47.4 \pm 2.9 \%$ c.p.m. $/ 20 \mathrm{mg}$ tissue) was greater $(P<0.05)$ than that determined for testicular homogenates of control rats $(38.5 \pm 2.0 \%)$. Scatchard plots of actual binding data are presented in Text-fig. 1 . Increasing mass of hCG was added to duplicate tubes containing $20 \mathrm{mg}$ testicular tissue and the linear plots of B/F ( ${ }^{125}$ I-labelled hCG) versus $B(\mathrm{pM})$ demonstrated that association constants were similar for scrotal testes $\left(K_{\mathrm{a}}=1.6 \times 10^{10} \mathrm{M}^{-1}\right)$ and cryptorchid testes $\left(K_{\mathrm{a}}=2.1 \times 10^{10}\right.$ $\mathbf{M}^{-1}$ ). The number of binding sites $/ 20 \mathrm{mg}$ scrotal and abdominal testicular tissue was 25 and $32.5 \mathrm{fmol}$, respectively. Based on average testicular weights, maximal hCG binding was approximately $62.5 \mathrm{ng} / \mathrm{g}$ scrotal testicular tissue $(219 \mathrm{ng} /$ paired testes $)$ and approximately $81 \mathrm{ng} / \mathrm{g}$ abdominal testicular tissue ( $75 \mathrm{ng} /$ paired testes).

\section{Discussion}

Gross changes occur in the germinal epithelium after induced cryptorchidism, but changes in the morphological and biochemical functions within the interstitial compartment are ill-defined (Bergh \& Damber, 1978). Increased numbers (Clegg, 1961) and size of Leydig cells (Damber, Bergh \& Janson, 1978; Kerr et al., 1979) have been reported for abdominal testes. Combined with a change in the pituitary-testicular endocrine axis (Swerdloff et al., 1971; Rager et al., 1975; Gomes \& Jain, 1976; de Kretser et al., 1979) of the cryptorchid rat, Leydig cell damage 
and malfunction seem apparent. Hauger, Chen, Kelch \& Payne (1977) have concluded that the normal testis depends on anterior pituitary hormones for maintenance of testicular LH receptors and testosterone secretion and so the imbalance in gonadotrophin secretion imposed by cryptorchidism may have affected both.

A transient decrease in serum testosterone has been noted after induced cryptorchidism (Gomes \& Jain, 1976), but near-normal androgen concentrations were attained in the present study by 30 days after surgery. The responses of normal and cryptorchid rats to intravenous hCG were also equivalent in this study, although Kerr et al. (1979) reported a diminished testosterone response to hCG administration in cryptorchid rats.

Basal and hCG-stimulated androgen production in vitro confirm the findings of de Kretser $e t$ $a l$. (1979) and emphasize the need to investigate further the differences between in-vitro and invivo testosterone production by scrotal and abdominal testes.

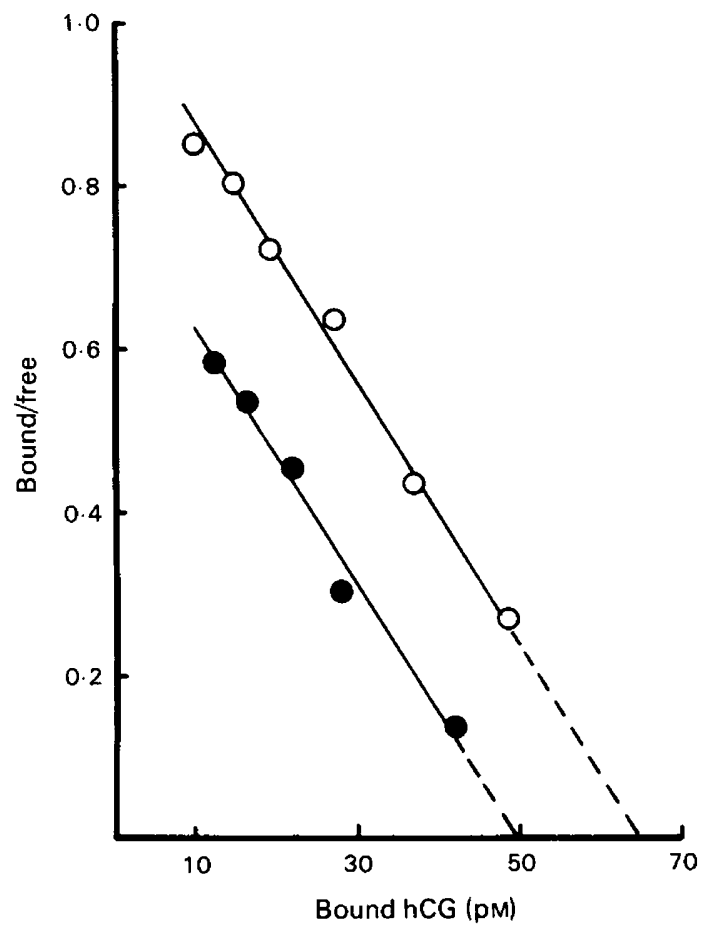

Text-fig. 1. Scatchard plots for specific binding of ${ }^{125}$ I-labelled hCG to testicular homogenates of a normal male rat $(O)$ and a cryptorchid rat $(O)$. The affinity constant $\left(K_{\mathrm{a}}\right)$, calculated from the slopes, was approximately $2 \times 10^{10} \mathrm{M}^{-1}$ for both scrotal and abdominal testes. The number of binding sites, taken from the $x$ intercepts, was $1.25 \mathrm{pmol} / \mathrm{g}$ scrotal testis and $1.62 \mathrm{pmol} / \mathrm{g}$ abdominal testis. Molecular weight of hCG was taken as 50000 .

Scatchard analysis of testicular hCG binding indicates that receptor affinity is not affected by cryptorchidism but that capacity to bind hCG is decreased. Total binding capacity was nearly 3 times greater in scrotal testes than in abdominal testes. Frowein \& Engel (1975) obtained a similar value of $95 \mathrm{ng} / \mathrm{g}$ normal scrotal testis tissue, and found enhanced binding capacity in cryptorchid testes relative to normal when expressed on a per unit protein basis, although Hagenäs, Ritzén, Svensson, Hansson \& Purvis (1978) and de Kretser et al. (1979) reported a substantial decrease in binding capacity when expressed on a per testis basis. Importantly, the association constant $\left(K_{\mathrm{a}}=10^{10} \mathrm{M}^{-1}\right)$ and number of binding sites $\left(\mathrm{Q}=10^{-12}\right.$ $\mathrm{mol} /$ testis) reported previously for the intact rat (Catt \& Dufau, 1973a; Frowein \& Engel, 1975) 
and that reported here are similar. The paradoxical relationship between hCG binding capacity and in-vitro androgen production by cryptorchid testes is misleading because ultrastructural characteristics of the Leydig cells from abdominal testes suggest that these cells are extremely steroidogenically active (Kerr et al., 1979). The phenomenon of "spare receptors" described by Catt \& Dufau (1973b) seems to be an inherent characteristic of the normal rat testis and that elevated levels of gonadotrophins in cryptorchid rats decrease testicular $\mathrm{LH} / \mathrm{hCG}$ receptors by autoregulation. A moderate reduction in $\mathrm{LH} / \mathrm{hCG}$ receptors in the normal rat testis does not seem to affect androgen production capability (Purvis, Torjesen, Haug \& Hansson, 1977; Pirke, Vogt \& Geiss, 1978; Purvis, Clausen, Brandtzaeg \& Hansson, 1978; Sharpe \& McNeilly, 1978). Although this conclusion can explain the normal androgen response to hCG in vivo, it fails to explain the enhanced response of the cryptorchid testis in vitro. The dose-response study conducted by de Kretser et al. (1979) suggests that the discrepancy between testosterone production in vivo and in vitro might depend on the degree of gonadotrophic stimulation being given; but this and other hypotheses need critical evaluation.

Special thanks to Ms Becky Chmelka, Ms Donna Taubenheim and Ms Marilyn Bierman for technical assistance, and to NIAMDD, Bethesda, Maryland, for purified hCG. Co-operation of the Nebraska Agricultural Experiment Station, University of Nebraska, Lincoln, is gratefully acknowledged.

\section{References}

Aafjes, J.H., Vreeburg, J.T.M. \& Schenck, P.E. (1978) Serum gonadotrophins in rats after castration or heat treatment of the testes. Acta endocr., Copenh. 88, $260-273$.

Amatayakul, K., Ryan, R., Uozumi, T. \& Albert, A. (1971) A reinvestigation of testicular-anterior pituitary relationships in the rat. I. Effects of castration and cryptorchidism. Endocrinology 88, 872-880.

Bartke, A., Williams, K.I.H. \& Daiterio, S. (1977) Effects of estrogens on testicular testosterone production in vitro. Biol. Reprod. 17, 645-649.

Bergh, A. \& Damber, J.E. (1978) Morphometric and functional investigation on the Leydig cells in experimental unilateral cryptorchism in the rat. Int. $J$. Androl. 1, 549-562.

Bex, F.J. \& Bartke, A. (1977) Testicular LH binding in the hamster: modification by photoperiod and prolactin. Endocrinology 100, 1223-1226.

Catt, K.J. \& Dufau, M.L. (1973a) Spare gonadotrophin receptors in rat testis. Nature, New Biol. 244, 219 221.

Catt, K.J. \& Dufau, M.L. (1973b) Interactions of LH and hCG with testicular gonadotropin receptors. In Receptors for Reproductive Hormones, pp. 379-418. Eds B. W. O'Malley \& A. R. Means. Plenum Press, New York.

Clegg, EJ. (1961) Further studies on artificial cryptorchidism: quantitative changes in the interstitial cells of the rat testis. J. Endocr. 21, 433-441.

Damber, J.E., Bergh, A. \& Janson, P.O. (1978) Testicular blood flow and testosterone concentrations in the spermatic venous blood in rats with experimental cryptorchidism. Acta endocr., Copenh. 88, 611-616. de Kretser, D.M., Sharpe, R.M. \& Swanston, I.A. (1979) Alterations in steroidogenesis and human chorionic gonadotropin binding in the cryptorchid rat testis. Endocrinology 105, 135-138.

Dufau, M.L., Catt, K.J. \& Tsuruhara, T. (1971) Gonadotrophin stimulation of testosterone production by the rat testis in vitro. Biochim. Biophys. Acta 252, 574-579.

Frowein, J. \& Engel, W. (1975) Binding of human chorionic gonadotrophin by rat testis: effect of sexual maturation, cryptorchidism and hypophysectomy. $J$. Endocr. 64, 59-66.

Gomes, W.R. \& Jain, S.K. (1976) Effect of unilateral and bilateral castration and cryptorchidism on serum gonadotrophins in the rat. J. Endocr. 68, 191-196.

Hagenäs, L., Ritzén, E.M., Svensson, J., Hansson, V. \& Purvis, K. (1978) Temperature dependence of sertoli cell function. Int. J. Androl., Suppl. 2, 449-458.

Hauger, R.L., Chen, Y.-D.I., Kelch, R.P. \& Payne, A.H. (1977) Pituitary regulation of Leydig cell function in the adult male rat. J. Endocr. 74, 57-66.

Kerr, J.B., Rich, K.A. \& de Kretser, D.M. (1979) Alterations of the fine structure and androgen secretion of the interstitial cells in the experimentally cryptorchid rat testis. Biol. Reprod. 20, 409-422.

Lloyd, B.J. (1972) Plasma testosterone and accessory sex glands in normal and cryptorchid rats. J. Endocr. 54, 285-296.

Pirke, K.M., Vogt, H.-J. \& Geiss, M. (1978) In vitro and in vivo studies on Leydig cell function in old rats. Acta endocr., Copenh. 89, 393-403.

Purvis, K., Torjesen, P.A., Haug, E. \& Hansson, V. (1977) hCG suppression of LH receptors and responsiveness of testicular tissue to hCG. Mol. Cell. Endocr. 8, 73-80. 
Purvis, K., Clausen, O.P.F., Brandzaeg, P. \& Hansson, V. (1978) LH receptors and Leydig cell responsiveness to hCG in vitro. Arch. Androl. 1, 299-310.

Rager, K., Zarzychi, J., Eichner, M. \& Gupta, D. (1975) Effects of experimental bilateral cryptorchidism and castration on the plasma gonadotropins in male rats during sexual maturation. Res. exp. Med. 165, 55-59.

Scatchard, G. (1949) The attractions of proteins for small molecules and ions. Ann. N. Y. Acad. Sci. 51, 660-672.

Schanbacher, B.D. (1976) Rapid chromatography for quantitation of radioimmunoassayable $5 \alpha$-androstane-17 $\beta$-ol-3-one and testosterone in ram, bull and boar serum. Endocr. Res. Commun. 3, 71-82.
Schanbacher, B.D., Gomes, W.R. \& VanDemark, N.L. (1974) Testicular carnitine acetyltransferase activity and serum testosterone levels in developing and cryptorchid rats. J. Reprod. Fert. 41, 435-440.

Sharpe, R.M. \& MeNeilly, A.S. (1978) Gonadotrophininduced reduction in LH-receptors and steroidogenic responsiveness of the immature rat testis. Int. $J$. Androl., Suppl. 2, 264-275.

Swerdloff, R.S., Walsh, P.C., Jacobs, H.S. \& Odell, W.D. (1971) Serum LH and FSH during sexual maturation in the male rat: effect of castration and cryptorchidism. Endocrinology 88, 120-128.

Received 10 October 1979 